\title{
Biogeographic barriers in north-western Australia: an overview and standardisation of nomenclature
}

\author{
Mark D. B. Eldridge ${ }^{\mathrm{A}, \mathrm{D}}$, Sally Potter ${ }^{\mathrm{A}}$ and Steven J. B. Cooper ${ }^{\mathrm{B}, \mathrm{C}}$ \\ ATerrestrial Vertebrates, Australian Museum, 6 College Street, Sydney, NSW 2010, Australia. \\ ${ }^{\mathrm{B} S}$ chool of Earth \& Environmental Science and Australian Centre for Evolutionary Biology and Biodiversity, \\ University of Adelaide, SA 5005, Australia. \\ ${ }^{C_{E}}$ volutionary Biology Unit, South Australian Museum, SA 5000, Australia. \\ DCorresponding author. Email: mark.eldridge@austmus.gov.au
}

\begin{abstract}
Additional keywords: barriers, biogeography, Kimberley, northern Australia, Top End, vicariance.
\end{abstract}
Received 25 January 2012, accepted 14 February 2012, published online 13 March 2011

Within Australia, the biodiverse monsoon tropics are of considerable biogeographical interest. However, this vast and relatively undisturbed area with its high endemicity has only recently become the focus of phylogeographic research (Bowman et al. 2010; Fujita et al. 2010; Melville et al. 2011; Toon et al. 2010). A major challenge to understand the biogeographical processes that have shaped the distribution and diversity of taxa in this region is the lack of detailed fossil and palaeoecological data (Bowman et al. 2010). Although molecular data are able to contribute to our understanding of the biogeographic history of the region (e.g. Lee and Edwards 2008; Toon et al. 2010), relatively few studies have focussed on the geologically old and topographically complex northwest region of Australia (Jennings and Edwards 2005; Fujita et al. 2010; Melville et al. 2011). It is becoming increasingly clear that the biogeographic patterns of this region and the accompanying terminology are complex (Potter et al. 2012). Here we seek to provide an historical overview of the biogeographic nomenclature used for this region in order to bring greater clarity and concordance. We also propose a standard nomenclature that could be used in future biogeographic/phylogeographic studies of north-western Australia.

The tropical monsoon region of north-western Australia represents a unique biome comprising a range of habitats. Proterozoic sandstone dominates the landscape and forms ranges and dissected escarpments set within widespread savannah woodlands. Smaller areas of monsoon rainforest, gallery forest and seasonally wet grasslands also occur. The monsoonal climate is characterised by dry winters and wet summers, which drives the vegetation type and associated distribution of taxa (Bowman et al. 2010). Tropical habitats contracted north during aridification in the Miocene and late Pliocene and the monsoonal conditions commenced following the rise of the Tibetan Plateau (3.4-7.2 million years ago) and the closing of the Isthmus of Panama (see Bowman et al. 2010;
Fujita et al. 2010). However, it was not until the Pleistocene that the monsoonal tropics experienced fluctuating environmental changes associated with global glacial cycles that developed the more contemporary arid-adapted vegetation (reviewed in Bowman et al. 2010; Fujita et al. 2010). The less topographically complex lowlands between the disjunct sandstone outcrops have been identified as potential biogeographic barriers for a wide variety of fauna (e.g. Bowman et al. 2010).

Keast (1961) regarded north-west Australia (including both the Kimberley region and Top End of the Northern Territory, Fig. 1) as a single major mesic refuge area (North-West refuge) for Australian fauna. Earlier, Keast (1958) noted that the region of the Joseph Bonaparte Gulf formed a distributional barrier for some mangrove-dependent birds, due to a lack of habitat.

After an examination of the North-West refuge bird fauna, Ford (1978) identified the presence of three 'minor biogeographic barriers' in the region between the Kimberley and northern Northern Territory (i.e. the Top End). These were identified as 'arid country round the Joseph Bonaparte Gulf and the Victoria River valley, a discontinuity in sandstone ranges in the region of the Daly River drainage and a stretch of coastline poor in mangroves on western side of the Joseph Bonaparte Gulf'. More specifically, the lowlands of the Daly River drainage were identified as a significant barrier for many sandstone-rangeadapted taxa (Ford 1978). The arid country around the head of the Joseph Bonaparte Gulf (in the region of the Ord and Victoria Rivers) was considered a significant barrier for monsoon and gallery forest species, as well as for moist grassland taxa, while the break in mangrove habitat in the western Joseph Bonaparte Gulf had significantly influenced mangrove specialists (Ford 1978). This later gap in the distribution of mangroves was subsequently examined in greater detail by Ford (1982), who identified it as a significant biogeographical barrier for mangrove birds, which he termed the 'Bonaparte Gap'. Subsequently, 'Bonaparte Gap' has entered the literature as a more general term 
for the break in distribution between many Kimberley and Top End taxa (e.g. Ford 1987; Braby 2008; Toon et al. 2010).

The other two biogeographic barriers identified, but not named, by Ford (1978) have also subsequently become more widely adopted: the strip of arid country at the head of the Joseph Bonaparte Gulf became known as the 'Ord Arid Intrusion' (e.g. Woinarski 1992; Ford and Blair 2005; Bowman et al. 2010; Melville et al. 2011), and the lowlands of the Daly River region as the 'Victoria River Drainage Barrier' (Schodde and Mason 1999; Joseph and Omland 2009). Along with the previously mentioned 'Bonaparte Gap', these two terms have tended to lose their original narrow meaning (i.e. Ford 1978) in recent usage, with each being used largely interchangeably to refer more generally to a single biogeographic barrier separating many Kimberley and Top End taxa. In addition, Cracraft (1986, 1991) (referencing Ford 1978) defined this barrier as the lowlands of the Victoria and Daly Rivers, while Jennings and Edwards (2005) used the term 'Kimberley Plateau-Arnhem Land Barrier' to describe the barrier comprising the Ord, Victoria and Daly River valleys, again referencing Ford (1978). The variety of terms and definitions currently in use has resulted in a rather confused literature.

A recent phylogeographic study (Potter et al. 2012) of the brachyotis species group of rock-wallabies (Petrogale), endemic to north-west Australia, has provided the first molecular evidence that this region consists of a series of biogeographic barriers spread over $\sim 500 \mathrm{~km}$. Since several of the barriers identified in this study are coincident with previously named biogeographic barriers, there is now a need for the standardisation of definitions and greater consistency in usage, so that both broad and narrow definitions can be unambiguously communicated and tested in future studies.

We propose that the term 'Kimberley Plateau-Arnhem Land Barrier' be applied to the whole region and its broad biogeographic impact. Each of the more localised and specific barriers should then be defined as follows:

- 'Bonaparte Gap': the break in mangrove habitat on the western side of the Joseph Bonaparte Gap (Fig. 1),

- 'Ord Arid Intrusion': arid country and lowlands surrounding the Ord River basin (Fig. 1),

- 'Victoria River Drainage' Barrier: low arid country and break in sandstone structure surrounding the Victoria River valley (Fig. 1),

- 'Daly River Drainage' Barrier: lowlands and major discontinuity in sandstone ranges surrounding the Daly River drainage (Fig. 1).

Potter et al. (2012) have also detected the molecular signal of an additional potentially novel barrier in the central Kimberley, which they term the 'East-West Kimberley Divide' (Fig. 1). Currently, the precise location and nature of this barrier is unclear. It is also uncertain whether a similar phylogeographic break occurs in other Kimberley taxa. As suggested by Potter et al. (2012), this putative barrier may be related to the presence of a band of basalt country that runs from north to south through the central Kimberley, or it could represent a boundary between populations that expanded from past mesic refugia within the Kimberley. Intriguingly, the biogeographically significant break

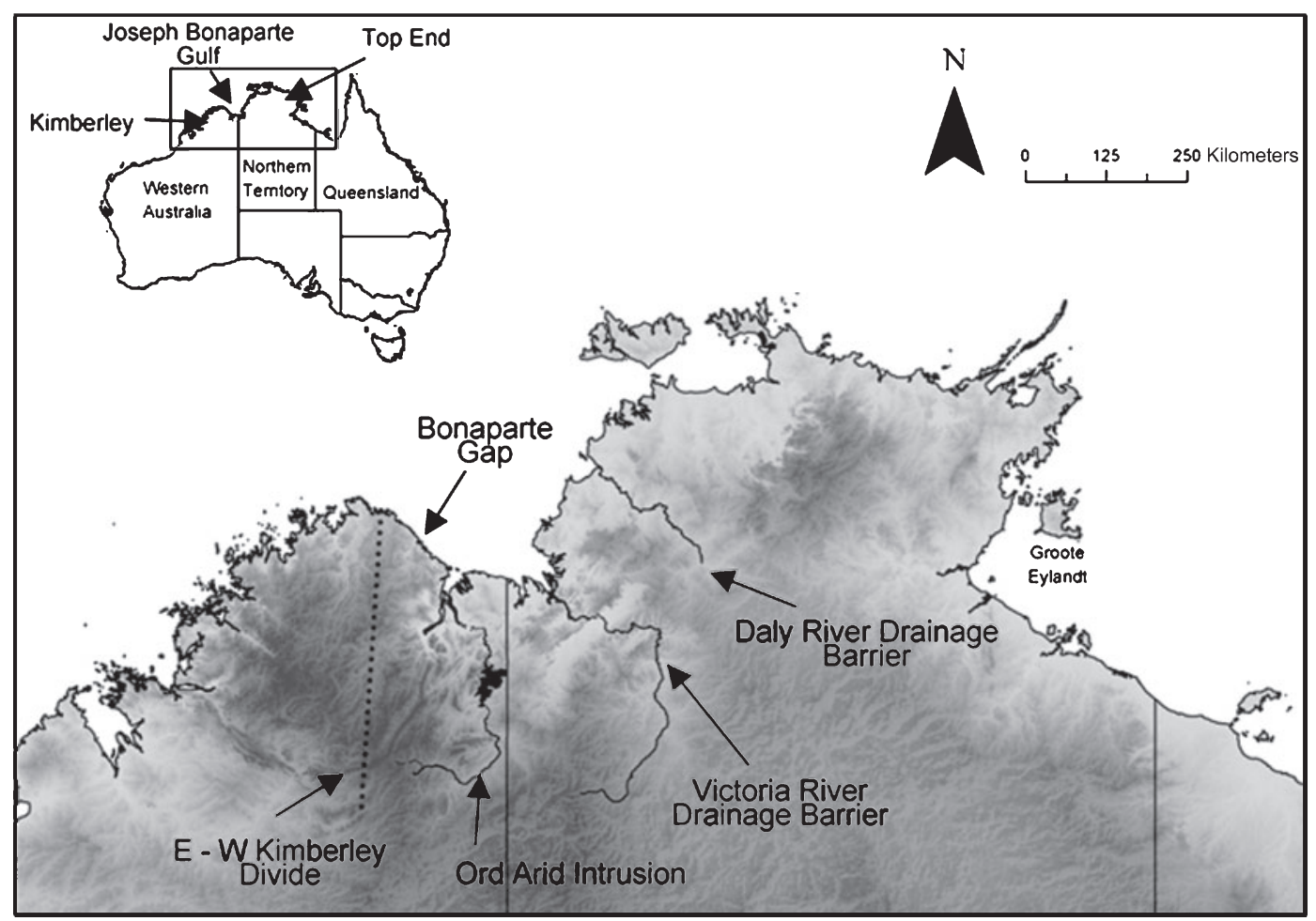

Fig. 1. North-west Australia, showing the location of the identified biogeographic barriers. Increasing elevation is indicated by darker shading (up to $\sim 1000 \mathrm{~m}$ ). 
in coastal mangrove habitat (i.e. the Bonaparte Gap) also occurs in this general area, as does the boundary between two major freshwater fish biogeographic Provinces (Unmack 2001), further hinting that some significant landscape feature or combination of geoclimatic attributes has significantly impacted gene flow in a variety of taxa in this region.

Additional phylogeographic studies of a variety of codistributed taxa are now urgently needed in order to better understand and characterise the East-West Kimberley Divide and the other barriers identified within north-west Australia. It will be important that both habitat specialist and generalist species are examined, since the impact of the identified barriers is likely to vary considerably in intensity through both time and space, depending on species biology and the habitat occupied. Potter et al. (2012) found different levels of divergence across different barriers, indicating that vicariance was not a one-off event, but likely to be a recurrent process. These additional studies will enable a much clearer picture of the evolutionary history of this region to emerge and enable the impact of landscape features and climatic changes in shaping the distribution of biodiversity to be assessed.

\section{Acknowledgements}

We thank Michael Elliott for preparing Fig. 1.

\section{References}

Bowman, D. M. J. S., Brown, G. K., Braby, M. F., Brown, J. R., Cook, L. G., Crisp, M. D., Ford, F., Haberle, S., Hughes, J., Isagi, Y., Joseph, L., McBride, J., Nelson, G., and Ladiges, P. Y. (2010). Biogeography of the Australian monsoon tropics. Journal of Biogeography 37, 201-216. doi:10.1111/j.1365-2699.2009.02210.x

Braby, M. F. (2008). Biogeography of butterflies in the Australian monsoon tropics. Australian Journal of Zoology 56, 41-56. doi:10.1071/ZO08021

Cracraft, J. (1986). Origin and evolution of continental biotas: speciation and historical congruence within the Australian avifauna. Evolution 40, 977-996. doi:10.2307/2408757

Cracraft, J. (1991). Patterns of diversification within continental biotas: hierarchical congruence among the areas of endemism of Australian vertebrates. Australian Systematic Botany 4, 211-227. doi:10.1071/ SB9910211

Ford, J. (1978). Geographical isolation and morphological and habitat differentiation between birds of the Kimberley and the Northern Territory. Ети 78, 25-35. doi:10.1071/MU9780025

Ford, J. (1982). Origin, evolution and speciation of birds specialized to mangroves in Australia. Ети 82, 12-33. doi:10.1071/MU9820012

Ford, J. (1987). Minor isolates and minor geographic barriers in avian speciation in continental Australia. Ети 87, 90-102. doi:10.1071/ MU9870090
Ford, F., and Blair, D. (2005). Neat patterns with a messy history: savannah refuges in northern Australia. Mammal Study 30, S45-S50. doi:10.3106/ 1348-6160(2005)30[45:NPWAMH]2.0.CO;2

Fujita, M. K., McGuire, J. A., Donnellan, S. C., and Moritz, C. (2010). Diversification and persistence at the arid-monsoonal interface: Australia-wide biogeography of the Bynoe's gecko (Heteronotia binoei; Geckkonidae). Evolution 64, 2293-2314.

Jennings, W. B., and Edwards, S. V. (2005). Speciational history of Australian grass finches (Poephila) inferred from thirty gene trees. Evolution 59, 2033-2047.

Joseph, L., and Omland, K. (2009). Phylogeography: its development and impact in Australo-Papuan ornithology with special reference to paraphyly in Australian birds. Ети 109, 1-23. doi:10.1071/MU08024

Keast, J. A. (1958). Variation and speciation in the Australian flycatchers. Records of the Australian Museum 24, 73-108. doi:10.3853/j.00671975.24.1958.646

Keast, J. A. (1961). Bird speciation on the Australian continent. Bulletin of the Museum of Comparative Zoology 123, 303-495.

Lee, J. Y., and Edwards, S. V. (2008). Divergence across Australia's Carpentarian Barrier: statistical phylogeography of the red-backed fairy wren (Malurus melanocephalus). Evolution 62,3117-3134. doi:10.1111/ j.1558-5646.2008.00543.x

Melville, J., Ritchie, E. G., Chapple, S. N. J., Glor, R. E., and Schulte, J. A. (2011). Evolutionary origins and diversification of dragon lizards in Australia's tropical savannas. Molecular Phylogenetics and Evolution 58, 257-270. doi:10.1016/j.ympev.2010.11.025

Potter, S., Eldridge, M. D. B., Taggart, D. A., and Cooper, S. J. B. (2012). Multiple biogeographic barriers identified across the monsoon tropics of northern Australia: phylogeographic analysis of the brachyotis group of rock-wallabies. Molecular Ecology, in press.

Schodde, R., and Mason, I. J. (1999). 'The Directory of Australian Birds.' (CSIRO Publishing: Melbourne.)

Toon, A., Hughes, J. M., and Joseph, L. (2010). Multilocus analysis of honeyeaters (Aves: Meliphagidae) highlights spatio-temporal heterogeneity in the influence of biogeographic barriers in the Australian monsoonal zone. Molecular Ecology 19, 2980-2994. doi:10.1111/j.1365-294X.2010.04730.x

Unmack, P. J. (2001). Biogeography of Australian freshwater fishes. Journal of Biogeography 28, 1053-1089. doi:10.1046/j.1365-2699. 2001.00615.x

Woinarski, J. C. Z. (1992). Biogeography and conservation of reptiles, mammals and birds across north-western Australia: an inventory and base for planning an ecological reserve system. Wildlife Research 19, 665-705. doi:10.1071/WR9920665

Handling Editor: Paul Cooper 